\title{
Linguistic and Cultural Transfer in Euphemistic Naming of Social Diseases
}

\author{
Andrey G. Fomin* and Evgeniia V. Arkhipova \\ Kemerovo State University \\ 6 Krasnaia Str., Kemerovo, 650043, Russia
}

Received 23.11.2017, received in revised form 18.12.2017, accepted 11.01.2018

\begin{abstract}
The objectives of this study include identification of general patterns of euphemisms referring to social diseases, establishing of specific euphemisms for social diseases, and identification of the euphemism's susceptibility to linguistic and cultural transfer. Based on scientific or popular scientific articles, our analysis of euphemisms resulted, according to subject matter, in distinguishing six separate categories: 1) medical deception; 2) incurable diseases, or possibly lethal diseases; 3) sexually transmitted diseases; 4) physical abnormalities, 5) mental abnormalities; and 6) addictions. As a result, we should note that substitutive names are predominantly represented with foreign words acquired through linguistic and cultural transfer from English into Russian, as well as from Latin and Greek. Besides, they are mainly words with generalized semantics. The specificity of euphemistic formation and the use of such terms often depends on the features of the professional environment where they are used, as well as on general goals and objectives of a certain professional activity. In this case, medical ethics and medical secrecy play an important role.
\end{abstract}

Keywords: linguistic and cultural transfer, euphemism, social disease.

DOI: 10.17516/1997-1370-0205.

Research area: philology.

In modern linguistics, the term language means a continuous creative process reflecting the features of people's worldview used in everyday life. A language is not just a means of communication, it is also a system that both reflects human nature and accumulates all the necessary information and knowledge the man has about the world and himself/herself. The language determines the connection of each person's thinking with the ideas formed within the society; it is a link between the culture and the ethno-cultural community. According to
N. Bochegova, language is more than just a tool for expressing ideas, as every language is a means of categorizing experience (Bochegova et al., 2011). Language is a natural basis of every culture, affecting all its layers and serving as a means of ordering the world and consolidating the ethnic worldview. Consequently, language is considered to be the main part of every national culture, while social experience featuring each national culture imposes a certain imprint on it. In this case, in order to name various objects and phenomena, people representing different

(C) Siberian Federal University. All rights reserved

* Corresponding author E-mail address: andfomin67@mail.ru 
cultures and speaking different languages use different realities reflecting their way of life, customs, and traditions. Thus, language represents people's spiritual component, i. e. their mentality.

In scientific literature, the term mentality refers to a stereotyped set to perceive a naïve worldview through the prism of the values of ethno-cultural consciousness. When describing the concept of mentality, S. Ter-Minasova states that it includes the mindset, attitude, world perception, and psychology. In other words, the mentality is the mental and spiritual mood of both the individual and the society as a whole (Ter-Minasova, 2008). M. Kondrat'ev gives the following definition: mentality is 'a system of specific mental life of people representing a particular culture; a qualitative combination of perception features and assessment of the world around them, conditioned by economic, political, and historical circumstances of the development of this particular community and manifested in an inherent behavioral activity' (Kondrat'ev et al., 2007). As A. Khrolenko reasonably insists, the mentality consists not so much of ideas but of feelings, moods, and opinions that subconsciously govern a person (Khrolenko, 2009).

The language and mentality are an integral part of culture and deemed to be necessary for thinking process. Thus, mentality is formed inseparably from the reality surrounding a person, under the influence of a social circle, and, consequently, a person copies the mentality of compatriots. The fact that people who speak different languages perceive the world differently confirms that the native language can shape the character and perception of the human world. Consequently, if people perceive the world differently, different language tools will be used to transmit information. However, even if people represent a single linguistic and cultural community (i. e. share the same language), any differences, for example, in their cultural experience or perception, often lead to various failures in the communication process. As the globalization seems inevitable, the information became more open, and certain linguistic cultures dominate in some spheres, for example, in health care more and more realia undergo the process of linguistic and cultural transfer.

Linguistic and cultural transfer is the transition, pass or borrowing of elements of one linguistic culture by the another one. This transfer can be observed both within the framework of one linguistic culture, for example, between different layers of society, and between several linguistic cultures, especially if it is a global sphere such as health care. Speaking about this sphere and social diseases, euphemism as a phenomenon should not go unmentioned, as it is caused by the specific character of medical activity, including the manifestation of professional etiquette, which is typical of all linguistic cultures. Therefore, it is possible to trace the transfer of various euphemisms meaning social diseases from one culture to another. Medical euphemisms can be considered in two aspects: 1) by characterizing thematic groups of the replaced names; 2) by linguistic generalization of euphemisms within the group, determination of the euphemism formation method and consideration of the question of whether the euphemisms concerned are conventional or occasional. The objectives of this study include identification of general patterns of euphemisms referring to social diseases, establishing of specific euphemisms for social diseases, and identification of the euphemism's susceptibility to linguistic and cultural transfer.

This study studies the euphemism in its broad sense as 'a word or expression meant under certain conditions to replace notions that the speaker find undesirable, quite impolite, or too harsh' (Krysin, 1996), and as 'emotionally 
neutral words or expressions used in place of synonymous words or expressions that appear to the speaker indecent, rude or tactless' (Arapova, 2003).

Based on scientific or popular scientific articles, our analysis of euphemisms used in speech resulted, according to subject matter, in distinguishing six separate categories: 1) medical deception; 2) incurable diseases, or possibly lethal diseases; 3) sexually transmitted diseases; 4) physical abnormalities; 5) mental abnormalities; and 6) addictions.

1) Medical practitioners often use the tactics of medical deception, as it accompanies a lot of situations that require mitigation, i. e. euphemization. Doctors often have to hide the truth in order to mitigate terrible information and not to hurt patients with their words. Primarily, this concerns cases associated with death and fatal diseases. A. Reformatsky noted that medical specialists 'often use Latin names of diseases (replace Russian words with Latin synonyms)'. Thus, when announcing the diagnosis, the doctor, to mitigate the effect, says to the patient: ' $Y$ вас не рак, а каниер' (Reformatskii, 1996). Some scholars oppose the deception, i.e. knowingly inaccurate information, on the one hand, and euphemia, on the other one. In this regard, V. Moskvin writes: 'The same technique (e. g. replacing one word with another one that would express a lesser intensity of the sign) can be used both to soften the expression (for example, overweight instead of fat), and to deceive (Chernobyl accident instead of nuclear disaster)' (Moskvin, 1999). According to the scientist, euphemism and deception are contrasted for their communicative purpose. However, E. Senichkina renounces to separate concepts of euphemia and deception in the theory of euphemia, since lies accompany many euphemisms of the Russian language and 'in practice the notions of veiling and misinforming euphemism are not contrasted, being contextual synonyms' (Senichkina, 2006). Examples include euphemisms denoting a psychiatric hospital, which appeared in Russian through borrowing from English language: bedlam, booby hatch, bughouse, funny farm, insane asylum, laughing academy, lunatic asylum, madhouse, mental health facility, birdhouse, padded cell, psycho ward, rubber room, sanatorium, snake pit. The same euphemisms are found in Russian: психбольница, канатчикова дача, вавилонское столпотворение, дом умалишенных, желтый дом, дурдом, дом хихи, дом ха-ха, скворечник, бедлам, санаторий, психлечебница, комната с резиновыми стенами, психушник, психушка. Here it is possible to trace the process of transferring the following names from English linguistic culture to the Russian one: bedlam - бедлам, rubber roот-комната с резиновыми стенами, insane asylum - психлечебница, laughing academy дом хи-хи/дом ха-ха, birdhouse - скворечник, sanatorium - санаторий, таdhouse - дурдом. These words are used in popular science articles: After coming home from the war with shell shock, Alex had to be held in a sanitarium - Раньше всех отправляли в спещиализированные санатории для восстановления после различных нервных срывов и истощений.

It should be noted that the use of hypernyms (клиника, санаторий, mental institution) is not connected with specialization of these hospitals.

2) Incurable diseases, or potentially lethal diseases (in the $19^{\text {th }}$ century, it refers mostly to tuberculosis; from the second half of the $20^{\text {th }}$ century - to cancer and cardiovascular diseases). A man always meets his grave due to a specific disease - either tumors, heart problems, or liver diseases. A. Solzhenitsyn described the rules of communication between cancerologists during their round: 'You couldn't be too outspoken during rounds either, you couldn't call a spade a spade and come to an agreement with each other. 
You couldn't even say that a patient's condition had worsened, all you could say was 'the process seems somewhat more acute'. Everything was discussed in euphemisms and half-allusions [...] Sometimes for the sake of better understanding they were allowed to use expressions like 'the shadow in the mediastinum has widened', or 'the case is not resectable', or 'we cannot exclude a lethal outcome' (which meant the man might die on the operating table) (Cancer Ward); - Short Latin terms, understood by selected people only. Possible oncological diagnosis is hidden with a special care. In this case, the Latin name cancer, thanks to linguistic and cultural transfer, entered both English and Russian linguistic cultures: Cancer incidence rates are lower in India than in Britain. - Bот начальные медицинские заключения и характеристика ее состояния, везде ужасное слово 'канцер' - латинское название онкологического заболевания.

Another example of linguistic and cultural transfer from English into Russian can be heart failure - сердечная недостаточность, which is replaced by a number of euphemisms: Your heart is not pumping properly; Your heart is a bit weaker than it used to be; Your heart is not working efficiently; Your heart, which is a pump, is not working as well as it should, causing back pressure on the lungs; You have fluid on your lungs, as your heart is not pumping hard enough; Your heart is not strong enough; Your heart is not as strong as it used to be (Moskvin, 1999). Декомпенсация сердиа; ослабление сократительной способности миокарда при его переутомлении, нарушение кровоснабжения тканей сердечной мышиы; застой крови в легких и в большом круге кровообращения, одышка, отеки, увеличение печени, асиит. Различают острую (астма сердечная) $и$ хроническую сердечную недостаточность, в поздних стадиях которой возникают необратимые нарушения обмена веществ и морфологические изменения в различных органах и тканях.

Euphemisms denoting diseases eventually become known to both patients and relatives, as a result, with the emergence of International Statistical Classification of Diseases and Related Health Problems (ICD-10), new means of mitigation and coding are borrowed from the English language. Russia joined ICD-10 in 1999. Examples include such euphemisms as: the Big $C$, growth, tumor. Thus, at the present time the cancer is called with the Latin name (cancer, or $C-r$ when abbreviated). Also we should note that written medical speech is characterized by the phenomenon of paraeuphemia, where diseases, their grades or individual symptoms are encrypted by using special numerical ciphers and graphic symbols. E. g.: H-90.3 - hearing loss; H-91.3 - deaf mutism; H-74.1 - adhesive otitis; $I V$ - grade when the cancer tumors are inoperable; a diagonal red line across a sheet means 'the patient with HIV'.

3) Sexually transmitted diseases. For a long time, these diseases were considered shameful and indecent. It was believed that these diseases were a result of human vices and a person's immoral behavior; or referred to diseases of the 'human bottom', i. e. gynecological and urological disorders caused by impurity. The naming unit соииально значимое заболевание, сате into Russian from the English social disease and was simply a euphemism for syphilis. In the historic context, syphilis was one of the most terrible diseases, as it caused the huge number of deaths, and also due to the attitude towards the genitals. It was believed that the physical symptoms of syphilis are caused by moral depravity. Thus, different words were used to describe it: social disease, S. T. D., V. D., treponemal disease, luetic disease from Latin lues, chancre - шанкр. Since France was blamed for spreading the disease to the rest of Europe, in the English language (and later 
in the Russian one), the word French was very common: French ache, French disease, French fever, French pox. In Russian: французский насморк (гусарский, парижский), ожерелье Венеры, купидонова болезнь. Франиузский насморк или гонорея - древнейший недуг, о котором есть упоминания даже в Библии, как о физической нечистоплотности.

Another disease that is also subject to frequent euphemization is AIDS. The fears and prejudices surrounding this disease led to the emergence of a number of naming units in the English language, which later, due to linguistic and cultural transfer, came into the Russian language. Correlation with homosexuality and people abusing intravenous drugs associates the disease with deviant behavior, as well as with moral and physical depravity. In this regard, before the word AIDS (СПИД) was accepted, the disease had changed many names. Today, to denote a person with the disease, acronyms $P W A$, PLA, and PLWA ('person living with AIDS') are widely used. Besides, the following naming units are frequently used: HIV (Human Immune Deficiency Virus)/ВИЧ(вирус иммунодефицита человека), HIV-positive, positive, immune failure. At the same time the abbreviation GRID (Gay Related Immune Deficiency) is neglected as the exclusive connection of the disease with the gay community turned out to be false.

4) Physical abnormalities. The euphemization of this thematic category does not concern specific medical words, but colloquial naming of a negating or hypernymic nature. In English there are such naming units as: differently abled, physically different, physically challenged, disabled. Influenced by the English language, the Russian language has recently acquired such hyperonyms as нетрудоспособный, травмированный, человек с физическими недостатками. For example: BONUCA has also supported activities geared towards promoting and protecting vulnerable groups, particularly women, children and the physically challenged.Анализ самооченки ученика с физическим недостатком - одна из основных иелей.

5) Mental abnormalities. Mental abnormalities and diseases, associated with the mental component, have long been a delicate topic, and their designations have also been euphemized. In English, as well as in Russian, there are a lot of euphemisms for mental abnormalities, which are mainly based on Greek or Latin words, e. g.: тапіа-мания and psychosisnсихоз, insanity - невменяемость, dementiaдемениия, lunacy - лунатизм. The word lunacy (лунатизм) derives from the Latin lune (moon), as then people believed that mental deviations were in close connection with moon phases. The very naming unit mad - сумастедший roots back to the medieval word amad which means 'to distract'. In Russian, the following euphemisms are most commonly used: душевная болезнь, психиическое расстройство, ментальное расстройство, психическое заболевание.

Currently, when classifying diagnoses of people suffering from mental disorders, the C3 code is used and was transferred into the Russian language.

6) Addictions. As social diseases (drug addiction, alcoholism, substance abuse) became widespread, the English language, and later the Russian one, acquired a whole series of euphemisms to mitigate the social acuteness of this issue. Thus, the naming unit addiction entered the Russian language as зависимость in a short while: The brain disease model of addiction: Assessing its validity, utility and implications for public policy towards the treatment and prevention of addiction. - И хотя пивной алкоголизм - болезнь, тоже чрезвычайно плохо поддаюшаяся лечению, он, конечно, гораздо менее опасен, чем героиновая зависимость. Another example 
is the naming unit weakness - слабость, е. g.: weakness for the drink - слаб до алкоголя means alcoholism, or weakness for the horses means the gambling addiction.

Euphemisms associated with problem gambling are usually replaced with the following expressions: to play or a game - uграть, игрок, bookmakers - букмейкеры, commission agents, turf accountants, игровые автоматы fruit machines. There are also a number of euphemisms associated with alcohol. The most common word is drink, which can be used either as a verb or a noun in the following phrases: have a drink, drink a lot, drink some or drink too much. In Russian, too, there are nominations associated with the verb numb, referring to alcohol: напиваться, выпивать, упиться, спиться. Other euphemisms where it is also possible to trace a linguistic and cultural transfer from English into Russian refer to states after the use of various substances, including alcohol and narcotic drugs: legless - не держаться на ногах, under the table - под столом, under the influence - быть под воздействием, spaced out - отлететь, overtired - опрокинуть, stewed-скурвиться, whistled-насвистеться, pickled - промариноваться. For example: The liver does most of our detoxing, so knowing how it ticks is crucial if you need to stay sober, or if you really want to get legless. $B$ связи с неумеренным употреблением спиртосодержащих жидкостей плохого качества он не в состоянии держаться на ногах, у него постоянно болит голова и почки.

Summarizing the foregoing, we should note that substitutive names are predominantly represented with foreign words acquired through linguistic and cultural transfer from English into Russian, as well as from Latin and Greek. Besides, they are mainly words with generalized semantics. Since the beginning of the $21^{\text {st }}$ century, due to the globalization and the accompanying process of linguistic and cultural transfer in English and Russian linguistic cultures, a redistribution of the composition within the thematic categories of euphemisms seems to be evident and results in six main categories of naming units most frequently euphemized. The specificity of euphemistic formation and the use of such terms often depends on the features of the professional environment where they are used, as well as on general goals and objectives of a certain professional activity. In this case, medical ethics and medical secrecy play an important role.

\section{References}

Akhmadullina, Kh.M. (2016). Zdorov'e naseleniia $i$ obrazovatel'naia politika [Health of the population and educational policy]. Ufa, Bratislava, $155 \mathrm{p}$.

Arapova, N.S. (2003). Evfemizm [Euphemism]. Moscow, Bol'shaia Rossiiskaia entsiklopediia, 704 p.

Barashenkov, V. (1999). Ekstrasensorika po gamburgskomu schetu [A Psychic according to the Hamburg account], In Znanie - sila [Knowledge is power], available at: http://www.znanie-sila.su/ (accessed 11 October 2017).

Bochegova, N.N., Grishkova, L.V., Portniagin, D.V., Stepanenko, O.A., Tsytsarkina, N.N. (2011). Teoriia i praktika filologicheskogo analiza teksta i diskursa [Theory and practice of philological analysis of text and discourse]. Kurgan, the Publishing House of Kurgan State University, 250 p.

Cancer Incidence in British Indians (2013). Available at: https://www.ncbi.nlm.nih.gov/pmc/ articles/PMC2905295/ (accessed 11 October 2017).

Health Library (2014). Available at: https://otvirusa.ru/nasmork/francuzskij-nasmork.html (accessed 11 October 2017). 
Heart failure: classification, symptoms and treatment (2013). Available at: http://kardioportal.ru/ content/serdechnaya-nedostatochnost-klassifikaciya-simptomy-i-lechenie (accessed 11 October 2017).

Hornby, Albert, Sydney. (2005). Oxford Advanced Learner's Dictionary of Current English, New York, Cambridge University Press, 1952 p.

Human rights annual report (2015). Available at: https://eeas.europa.eu/headquarters/ headquarters-homepage_en (accessed 11 October 2017).

Institute for Science and Ethics (2014). Available at: http://www.oxfordmartin.ox.ac.uk/event/1367 (accessed 11 October 2017).

Journal of Healthcare (2010). Available at: https://healthcare-communications.imedpub.com/ (accessed 11 October 2017).

Kabakov, A. (2000). Velikie stroiki apokalipsisa [Great constructions of the Apocalypse], In Kommersant'-Vlast', available at: http://www.kommersant.uk/

Khrolenko, A.T. (2009). Osnovy lingvokul'turologii [Basics of cultural linguistics]. Moscow, Flinta.Nauka, $184 \mathrm{p}$.

Kondrat'ev, M.Iu., Il'in, V.A. (2007). Azbuka sotsial'nogo psikhologa - praktika [The alphabet of the practicing social psychologist]. Moscow, Per Se, 464 p., available at: http://psychlib.ru/mgppu/ KAS/KAS-001.HTM\#\$p1 (accessed 11 October 2017).

Krysin, L.P. (1996). Evfemizmy v sovremennoi russkoi rechi Russkii [Euphemisms in modern Russian speech], In Russkii iazyk kontsa XX stoletiia [Russian language of the late $20^{\text {th }}$ century]. 2 , $28-49$

Krysin, L.P. (2012). Sovremennyi slovar' inostrannykh slov [The modern dictionary of foreign words]. Moscow, AST-PRESS KNIGA, 416 p.

Letov, G. (2003). Geroinovaia shkatulka [The box of heroin], In Ezhenedel'nyi zhurnal [Weekly magazine]. 25, 3.

Martin, E. (2015). New Concise Medical Dictionary, Oxford, Oxford University Press, 840 p.

Mosby (2012). Mosby's Medical Dictionary, St Louis, Elsevier: Health Sciences Division, 1984p.

Moskvin, V.P.(1999). Evfemizmy vleksicheskoi sisteme sovremennogo russkogo iazyka [Euphemisms in the lexical system of the modern Russian language]. Volgograd, Editorial URSS, $264 \mathrm{p}$.

Rawson, H. (1981). A Dictionary of Euphemisms and Other Doubletalk, New York, Crown Publishers, Inc., 312 p.

Petrova, M. (2003). Zdravookhranenie: realii dnia [Health: the realities of the day], In Mariiskaia Pravda, available at: https://www.marpravda.ru/news/sociym/ (accessed 11 October 2017).

Reformatskii, A.A. (1996). Tabu i evfemizmy [Taboo and euphemisms], In Vvedenie v iazykovedenie [Introduction to Linguistics], 536 p., available at: http://www.bsu.ru/content/page/1415/ hecadem/reformatsky_aa/reformatsky.pdf (accessed 11 October 2017)

Senichkina, E.P. (2006). Evfemizmy russkogo iazyka [Euphemisms of the Russian language]. Moscow, Vysshaia shkola, $151 \mathrm{p}$.

Ter-Minasova, S.G. (2008). Iazyk i mezhkul'turnaia kommunikatsiia [Language and crosscultural communication]. Moscow, Slovo, 264 p. 


\title{
Лингвокультурный трансфер \\ в эвфемизации номинаций сферы \\ социально значимых заболеваний
}

\author{
А.Г. Фомин, Е.В. Архипова \\ Кемеровский государственньй университет \\ Россия, 650043, Кемерово, ул. Красная, 6
}

В задачи настоящегго исследования входят выявление общзи закономерностей функиионирования эвфемизмов в сфере социально значимых заболеваний, установление специфики эвфемизмов сочиально значимых заболеваний, а также выявление подверженности эвфемизмов лингвокультурному трансферу. Анализ эвфемизмов, употребляемых в речи, сделанный на основе статей научного и научно-популярного характера показал, что по тематическому признаку выделяются, по крайней мере, шесть самостоятельных категорий: 1) врачебный обман; 2) категория неизлечимых заболеваний или заболеваний, могущих привести к смерти; 3) категория болезней, передаюшихся половым путем; 4) категория физических отклонений; 5) категория психических отклонений; 6) категория зависимостей. В результате можно сделать вывод, что замещующуе наименования преимущественно являются иноязычными словами, приобретенныли через лингвокультурный трансфер из английского языка в русский либо из латинского и греческого языка, а также являются словами с обобщуенной семантикой. Специфика образования и использования эвфемизмов зачастую зависит от особенностей профессиональной среды их употребления, а также от целей и задач профессиональной деятельности в целом, в данном случае немаловажную роль играет медицинская этика и врачебная тайна.

Ключевые слова: лингвокультурный трансфер, эвфемизм, соччиально значимые заболевания.

Научная специальность: 10.00.00 - филологические науки. 